\title{
Lingkungan Hidup dalam Perspektif Fikih
}

\author{
Asmuni Mth
}

The following article tries to explain Islamic law on environmental issues. Islamic Law should accomadate every sphere of human life, including the management of environment. In this relation, the position of human as Allah's vicegerence (Khalifah Allah) must responsible for their own deeds on the earth. For that reason, to formulate the contextual Islamic law on environmental problems, there are five principles, the principle of language, the goal of syariah, the condidition and the situation of society, the mutual complete, and rational. According to the writer, based on five principles should formulate and apply intellectual exercise of Islam (ijtihad) to solve and to develop environment figh.

Kata kunci: fiqh, khilafah, ijtihad,dan lingkungan.

\footnotetext{
Qudah menjadi keyakinan umat Islam Obahwa ajaran agama mereka solih likulli
} zaman wa makan, akomodatif terhadap berbagai situasi dan kondisi sosial masyarakat dalam mewujudkan kesejahteraan, membangun kebaikan, dan meningkatkan derajat hidup. Tidaklah berlebihan jika al-'Iz Ibn Abd Salam mengatakan, bahwa hukum Islam adalah untuk mewujudkan kemaslahatan umat manusia (limasalih al-anam). Hal ini tak lain karena manusia adalah objek yang menerima sekaligus subjek yang melaksanakan ajaran agama tersebut. Sehingga, mereka secara kodrati telah memiliki kedudukan yang baik di sisi Tuhan, Dzat yang menurunkan agama itu sendiri. Dengan demikian, wajarlah jika dengan status khalifatullah yang disandangnya, manusia berusaha menjaga kehormatan, mewujudkan kemaslahatan, dan memenuhi kebutuhan yang menyok.ong kehidupan mereka di muka bumi ini.

Untuk tujuan di atas, tawaran prinsip metodologi ijtihad dalam wilayah-wilayah lingkungan hidup terlebih dahulu perlu mendiskusikan fungsi kekhalifahan manusia dan tanggung jawab mereka dalam membuat perangkat aturan pengelolaan alam yang efektif dan fungsional. Pertanyaan teologis yang mengemuka adalah, siapakah yang dikuasakan oleh Tuhan untukmembuat dan merumuskan aturan-aturan tersebut? Dalam konsep al-wujud ada hubungan unilateral yang melakukan interaksi yaitu Allah, manusia dan alam (al-kaun). ${ }^{\prime}$ Namun kemudian, alam yang tidak dibekali dengan akal menjadi objek langsung cari aturan, sehingga ia bukan pihak yang

1 Muhammad 'Imarah, Ma'alim al-Minhaj al-sslami, Herndon, Virginia: al-Ma'had al-'Alami li al-Fikr al-Islami, Cet. II, 1411 H/1991, hal. 37. 
dilibatkan dalam membuat aturan. Dengan tidak terlibatnya alam dalam membuat aturan, maka interaksi berubah menjadi bilateral, yaitu antara Tuhan dan manusia. Namun, pertanyaan berikutnya adalah, siapakah yang membuat aturan-aturan dalam kehidupan umat manusia? Jawaban dari pertanyaan ini memosisikan keberadaan manusia pada wilayah khilafah sekaligus membatasi area pemikiran mereka. Karena diskusi tentang peran manusia dan tanggung jawab mereka terhadap Tuhan bagaikan lautan yang tak bertepi, sehingga pertanyaan dan jawabannya menjadi selalu aktual.

\section{Manusia sebagai Abdullah dan Khalilafatullah}

Al-Qur'an sebagai referensi sakral umat Islam mengandung dua bentuk petunjuk ${ }^{2}$ dalam mengatur kehidupan. Pertama, petunjuk bersifat langsung (hidayah mubasyarah) yang meliputi ketentuan hukum, akidah tentang ketuhanan, kenabian, hari kebangkitan dan pembalasan. Kedua, petunjukyang bersifat tidak langsung (hidayah gairu mubasyarah).

Isi al-Qur'an sesuai dengan fenomena alam. Tidak ditemukan di dalam al-Qur'an sesuatu yang bertentangan dengan kebenaran ilmu pengetahuan tentang alam, teori-teori akhlak dan lain-lain. Karena alQuran diturunkan oleh Maha Pencipta yang mengetahui rahasia dan hukum alam. ${ }^{3}$

Manusia dan alam sama-sama ciptaan Tuhan. Namun, manusia sebagai "makhluk fungsionil yang bertanggung jawab" memiliki keunggulan dalam penciptaan, karena diberi kemampuan berpikir untuk mengetahui hakikat dan fakta di dalam dan di luar dirinya. Keunggulan penciptaan manusia dengan yang lain terletak pada kombinasi tiga unsur sekaligus, yaitu unsur spiritual, unsur akal dan unsur material. Ketiga unsur ini mengantarkan mereka menjadi hamba Tuhan ('abdullah) yang patuh dan wakil Tuhan (khalifatullah) yang kreatif dan bertanggung jawab. Dengan akal, manusia mampu memilih, dan karenanya harus ditinggikan derajatnya. Inilah kreasi Tuhan terbesar yang membe-dakan manusia dari makhluk lain.

Sebelum Islam, sebagian orang memahami, bahwa tanggung jawab hanya dalam perspektif keduniaan, atau keakhiratan belaka. ${ }^{4}$ Akan tetapi, Islam menyatukan dan memadukan kedua bentuk tanggung jawab itu, karena manusia di satu sisi sebagai makhluk pribadi, dan di sisi lain sebagai anggota masyarakat. Kedua bentuk tanggung jawab itu memengaruhi perilaku manusia, karena setiap perilaku tidak bisa lepas dari tanggung jawab keduniaan dan keakhiratan. Tanggung jawab keduniaan merupakan tanggung jawab pendahuluan di hadapan masyarakat sebelum pada akhirnya tanggung jawab keakhiratan di depan Tuhan.

Kekhalifahan manusia disebutkan dalam surat al-Baqarah ayat 30 . Tugas kekhalifahan yang hanya dibebankan kepada manusia disebutkan dalam surat alAhzab ayat 72 . Kekuasaan manusia tidak bersifat total seperti halnya seorang pemilik jagat raya, melainkan kekuasaan dalam konteks wakil Tuhan di bumi seperti dijelaskan dalam surat al-Hadid ayat 7 . Setiap upaya untuk mewujudkan tugastugas kekhalifahan diatur dalam kontrak istikhlaf. Semua aktivitas yang bertujuan

2 Muhammad, Muhammad al-Madani, Khasais al-Quran al-Karim, Cet. I, 1422 H/2001 $M, t p$, hal. Il: 16 .

${ }^{3}$ Ibid. hlm. II: 11.

4 'Imarah, Ma'alim, hlm.37. 
untuk merealisasikan tugas-tugas kekhalifahan merupakan ibadah seperti disebutkan dalam surat al-Zariyat ayat 56 .

Manusia sebagai khalifah, mengemban amanah, tunduk pada ketentuanketentuan kontrak istikhlaf (pengangkatan khalifah). Ketundukan alam mengandung hikmah ilahiyah, yaitu menjadi fasilitas yang memudahkan manusia dalam melaksanakan tugas-tugas kekhalifahan. ${ }^{5}$ Dengan demikian, manusia menjadi mitra alam. la tundukpada hukum Tuhan demi kepentingan manusia seperti disebutkan dalam al-Qur'an surat Ibrahim ayat 32-33 dan surat Luqman ayat 20 . Jadi manusia dalam interaksi unilateral menduduki posisi al-wasth (penengah), al-'adl (penegak keadilan) dan al-haq (pencari kebenaran). ${ }^{6}$

\section{Wahyu Tuhan dan Rasio Manusia}

Penggunaan kata wahyu biasanya dimaksudkan pada kumpulan teks (nushush bentuk jamak dari nash). Kumpulan teks ini secara umum berbentuk khitab (Pernyataan) yang mengandung penjelasan tentang kehidupan, tujuan dari kehidupan, menetapkan kaidah-kaidah perilaku individu maupun masyarakat. Adapun istilah akal menunjuk pada dua makna yang berbeda dan saling berkaitan. Kata akal diartikan dengan prinsip-prinsip berpikir yang menetapkan proses berpikir setiap individu yang waras tanpa melihat latar belakang kebudayaan dan tingkat pendidikan. ${ }^{7}$ Akan tetapi, prinsip-prinsip akal paling penting adalah "prinsip tiada pertentangan". Sehingga, mustahil akan terjadi dalam satu waktu dua hal yang bertentangan, misalnya, jujur dan bohong, ada dan tidak ada dalam satu waktu. Dari uraian contoh ini, aka! merupakan alat untuk memperoleh ilmu pengetahuan, menguji data atau dalil-dalil hukum dan perma-salahan-permasalahan yang berkembang. Atas dasar ini, maka pengujian terhadap suatu persoalan mungkin hasilnya benar sejalan dengan prinsip akal, atau hasilnya tidak benar selanjutnya disebut tidak sejalan dengan prinsip-prinsip akal. Atas dasar pemahaman tentang akal ini, maka tidaklah benar mengatakan, bahwa wahyu tidak masuk akal (la aqlaniyah) kecuali kalau memang terjadi pertentangan internal antara teks-teks wahyu itu sendiri. ${ }^{\mathrm{B}}$

Namun, istilah akalbanyak digunakan untuk menunjuk kemampuan dan potensi seseorang dalam berpikir, sehingga akal merupakan alat berpikir untuk menetapkan kebenaran sesuatu berdasarkan data atau fakta. Akan tetapi, argurnen akal tentang kebenaran wahyu tidak menjadikan wahyu itu benar. Begitu juga sebaliknya, argumen akal yang menyatakan, ketidakbenaran wahyu tidak menjadikan wahyu itu tidak benar. Namun demikian, apabila akal melakukan penalaran yang valid (al-shari'h al-ma'qui), maka ia akan sesuai dengan wahyu yang ditransmisi secara sahih (alshahi'h al-manqu'l). Kesahihan proses transmisi data otoritatif melahirkan IImu Tafsir dan llmu Hadis yang kemudian menjadi landasan ilmu-ilmu lainnya dan landasan filsafat Islam. ${ }^{9}$ Paradigma ini melahirkan paradigma pokok-pokok agama dan cabang-cabangnya.

${ }^{5}$ Abdul Hamid Muhsin, Tajdid al-Fikr alIslami, Herndon, Virginia: al-Ma'had al-'Alami li al-Fikr al-Islami, Cet. l, $1416 \mathrm{H} / 1996 \mathrm{M}$, hlm. 146-150.

6 'Imarah. Ibid, hlm 37.

7 Luway Sofi, "Nahwa Minhajiyah Ushuliyah li al-Dirasat al-Islamiyah" dalam Fathi Hasan Malkawy dan Muhammad Abdu al-Karim Abu Sal, Buhus Mu'tamar 'Ulum alSyari'ah fi al-Jami'at, Amman Yordania: alMa'had al-'Alami li al-Fikr al-Islami, Cabang Yordania, Cet. I, 1995 M/14116 H, him. Il/331. s Ibid. 
Al-Qur'an dan Sunnah adalah rujukan sains dan menjadi "dalil" ilmu-ilmu. "Dalil" di sini dimaksudkan petunjuk adanya ilmuilmu, bukan ilmu itu sendiri. Oleh karena itu, sejarah menunjukkan adanya fakta, bahwa al-Qur'an mendorong umatnya untuk menciptakan ide-ide sains yang menjadi dasar ilmu-ilmu di kemudian hari. ${ }^{10}$

IImu-imu Islam dibangun atas dasar kebenaran-kebenaran yang bersifat otoritatif atau al-naqliyat wa al-mutawatirat, yakni para pemegang otoritas di bidangnya melalui data yang ditransmisi secara berkesinambungan; data empirik atau al-tajribat al-hissiyah yang meliputi al-hadasiyat wa al-mujarrabat. Ibnu Sina (Aviciena) ${ }^{11}$ membedakan antara penga-laman empirik yang disebut alhadasiyat dan al-mujarabat. Al-hadasiyat adalah data empirik yang terjadi di luar dan tanpa campur tangan kemampuan manusia untuk menciptakannya, seperti terjadinya gerhana, gempa bumi, dan sebagainya. Pengalaman empirik yang disebut a/mujarabat ialah pengalaman yang dapat diciptakan manusia atau dibuat eksperimen.

limu-ilmu Islam pun dibangun atas dasar kebenaran-kebenaran rasional ('aqliyah) yang melahirkan ilmu murni; ${ }^{12}$ dan, dibangun pula atas dasar pengetahuan intuitif (al-kasyfiyah). Pengetahuan terakhir ini memungkinkan lahirnya ilmu tasawuf 'amali, di samping tasawuf falsafi (filsafat tasawuf) dan tasawuf "ilmi (tasawuf ilmiyah). ${ }^{13}$ Paradigma ini melahirkan paradigma Persesuaian Akal dengan Wahyu.

Wahyu maupun akal dalam lingkaran al-wujud perspektif akidah memiliki keterkaitan yang erat. Akidah di samping menjadi titik tolak dalam berpikir dan berkreasi, juga dapat membatasi cara berpikir dan cara pandang manusia terhadap kehidupan. Dalam menyikapi masalah ini ilmuwan muslim terbagi menjadi tiga komunitas kecil. Pertama, komunitas muslim yang berpegang pada wahyu semata dan menafikan peran akal. Kedua, komunitas muslim yang berpegang pada akal semata dan menafikan peran wahyu. Dan ketiga, komunitas muslim yang berpedoman pada wahyu dan akal secara proporsional.

Gambaran tentang al-wujud tersebut akan menentukan siapa yang memiliki wewenang untuk membuat undang-undang, menetapkan fungsi manusia dan tujuan yang harus diwujudkan dalam kehidupan. Dalam ajaran Islam tujuan final dari kehidupan manusia adalah untuk mencari keridaan Allah (mardhatillah).

Wahyu adalah sarana untuk memperoleh ilmu. Sifat wahyu berupa al-Qur'an dan hadis mutawatir sudah pasti dan valid (qoth'i al-wurud). Sedangkan hadis (selain mutawatir) bersifat zannial-wund. Selain itu, wahyu juga bersifat mutlak tidak dapat diubah, apalagi diganti. Dilihat dari aspek pemaknaannya, wahyu terbagi menjadi dua: qathi ad-dalalah (hanya menerima satu makna), dan zanni ad-dalalah (menerima

"Ibn Taymiyah, "Minhaj al-Sunnah" dalam Juhaya S. Praja, Paradigma \& Penalaran Fiqh dalam Konteks Kekinian dan Keindonesiaan, makalah disampaikan dalam conference PPS IAIN/UIN se-Indonesia IAIN Ar-Raniry Darussalam Banda Aceh 1-5 Desember 2004.

${ }^{10}$ Fuad Sizkin, Tarikh al-Hadlarat wa alUlum al-Islamiyah, Riyadh, Universitas King Abdul Aziz; Abu Yalla, "al-'Uddah fi Syarh al'Umdah", dan syarahnya al-Kawkab al-Munir.

"Ibn Taymiyah, Al-Radd "ala alManthigiyin (Sanggahan terhadap Ahli-ahli Logika), Mesir, (n.d); Ibn Sina, al-Hidayah, Kairo, (n.d).

${ }^{12} \mathrm{Cf}$. Charles singer, dalam Juhaya S. Praja, hlm. 4.

13 Abdul Halim Mahmud, Falsafah alTashawwuf, Kairo: al-Risalat al-Qusyairiyah. 
makna yang beragam). Terlalu berlebihan dalam mengidentifikasi nash-nash qath'i sama artinya dengan memasung fleksibilitas wahyu. Padahal qoth'imaupun zannisejauh di luar kawasan teologis dan ibadah mahdhah masih mungkin dikonstruksi dan diintegrasikan dengan arus perubahan. Sebab kedua kategori pemaknaan terhadap wahyu tersebut mencerminkan keterbatasan nalar manusia dalam memahami dan mendialogkan nash dengan realitas sosial. Akibatnya, wahyu yang berwatak akomodatif berubah sikap menjadi otoriter dalam mengendalikan perkembangan zaman.

\section{Khilafah Sebagai Fungsi Eksistensial Manusia}

Dalam sistem akidah islamiyah dijelaskan bahwa semua al-wujud (yang ada) adalah makhluk atau ciptaan. Tuhan adalah Pencipta dan tempat kembali semua ciptaan. Proses penciptaan dan proses kembali kepada-Nya berjalan sesuai dengan hukum Allah. Namun dalam konteks alwujud dibedakan antara wujud al-Allah (keberadaan Tuhan) dan wujud al-kaun (keberadaan aiam). Wujud Zat Tuhan tidak dapat diraba, tetapi dapat diketahuj melalui indikasi-indikasi yang terdapat pada alam. Sedangkan wujud alam bersifat materiil dan dapat diraba serta memiliki kekurangan dan kelemahan (al-'ajz wa al-naqs). Jadi hubungan Allah dengan alam adalah hubungan Pencipta dengan ciptaan-Nya, atau hubungan antara yang mengatur dengan yang diatur. ${ }^{14}$

Dalam konteks khilafah mengenaj fungsi manusia di permukaan bumi dapat digolongkan menjadi tiga, yaitu manusia sebagai perusak (QS. 2: 30) dan (QS. 30: 41), manusia sebagai pencipta dan pembangun (QS. 11: 60) dan manusia sebagai pemelihara seperti ditegaskan dalam sebuah hadis kullukum ràin wa kullukum masulun an ra'iyatihi (semua manusia adalah pemelihara yang bertanggung jawab). Oleh karena itu, area khilafah adalah area perintah dan larangan Allah. Keduanya menuntut manusia untuk mengerjakannya secara konsisten dan berkesinambungan. Tentu saja dalam rangka mendekatkan diri dan mencari rida-Nya. Prioritas nama-nama sifat yang digunakan Allah untuk memperkenalkan diri-Nya kepada hamba atau disebut dengan istilah al-mutaqarrib bi al-faraid adalah dengan nama-nam al-âmir dan al-nâhi. Jadi bila seseorang menetapkan argumentasi ketuhanan, sebaiknya dengan melakukan af'âlu al-ta'ah atas al-âmirdan al-nâhi (taat terhadap perintah dan larangan Tuhan).

Dengan demikian sifat-sifat paling umum yang ada pada Tuhan adalah âmir dan nâhi. Sifat-Nya yang paling spesifik bahwa Dia adalah Allah. Dengan demikian, argumentasi teoritis tentang ketuhanan tidak dapat mendekati kebenaran kecuali kalau dibangun di atas dataran praktik (seperti alta'ah, (ketaatan), talab al-magfirah (memohon ampunan) dan al-taubah (bertaubat)) dan di atas sifat-sifat ketuhanan yang lebih umum (seperti al-âmir, al-nâhi, al-magfur, al-tawwab, al-rahim dan syadid al'iqab). Dari sini dapat disimpulkan bahwa pencermatan dan perenungan dalam wilayah ketuhanan tidak akan menjadi lurus dan tegak kecuali kalau disertai dengan 'amal atau perbuatan sesuai dengan tuntutan perintah dan larangan-Nya. Rasionalitas yang dibangun di atas pondasi 'amal akan lebih kaya, lebih

${ }^{14}$ Abdul Majid al-Najjar, Khilafat al-Insan bain al-Wahyu wa al-Aql, Herndon, Virginia: al-Ma'had al-'Alami li al-Fikr al-Islami, Cet. Il, $1993 \mathrm{M}$, hal. 120. 
dalam dan lebih benar dari rasionalitas teoritis yang terpisah dengan 'amal. ${ }^{15}$

Allah menggerakkan manusia untuk melaksanakan perintah dan larangan, atau disebut kontrak khilafah dengan mengombinasikan unsur spiritual dan material dalam penciptaan mereka. Dengan unsur spiritual manusia dapat memperoleh dan menghayati inti dari makna khilafah, yaitu menegakkan perintah dan larangan Allah. Dari unsur material manusia dapat secara langsung terdorong untuk membangun bumi. Kesanggupan manusia untuk mengemban amanah khilafah secara otomatis membuka peluang bagi manusia untuk sampai pada derajat yang tinggi yang mungkin tidak dimiliki oleh makhluk non mukallaf lain.

Sebagai makhluk hidup seperi juga makhluk-makhluk hidup lainnya, manusia dilengkapi dengan naluri "mempertahankan hidup" dan kecenderungan "hidup kekal". Namun demikian manusia juga mempunyai kesadaran dan kesabaran untuk mempertahankan hidup. Dan dari kesadaran dan kesabaran tersebut timbul dan berkembang daya pilih (ikhtiyar) dan daya upaya (kasb) manusia. Dari kemampuan memilih dan berkarya inilah kemudian berkembang kebudayaan dan peradaban manusia.

\section{Hakikat dan Karakteristik Akal}

Akal adalah alat untuk memperoleh, memahami dan membedakan sekaligus menghukum ilmu pengetahuan dan lain-lain. Akal menjadi tempat bergantungnya taklif dan manusia disebut mukallaf. Sasaran dari taklif terfokus pada tiga aspek yaitu; pengenalan manusia dengan Tuhan harus secara benar sehingga membuahkan pengabdian kepada yang Maha Pencipta; pemeliharaan dan pengembangan diri dalam perilaku dan perangai yang benar, adil, penuh kasih sayang dan etos kerja; pemeliharaan hubungan yang baik, damai dan rukun dengan lingkungan hidup.

Tugas akal adalah untuk memahami dan melaksanakan wahyu. Akal mengantar manusia untuk memperoleh kebenaran melalui penelitian dan berpikir. Aktivitas berpikir dan meneliti melalui tahepantahapan, berangsur-angsur tetapi tetap integral. ${ }^{16}$ Akal merupakan potensi manusia yang maha besar untuk memperoleh kebenaran. Namun keunggulan akal disertai dan diwarnai pula dengan berbagai bahaya, antara lain ketergesa-gesaan dan mengikuti hawa nafsu. Kelemahan-kelemahan yang dimiliki akal dapat menjerumuskan pada kesalahan. Kecuali kalau dipandu dengan metode berpikir yang benar, maka hasil nalar manusia juga dapat dipastikan benar. Namun kebenaran produk akal bersifat relatif dan terbatas, karena mengacu pada indera manusia yang kualifikasinya terbatas pula, terikat oleh waktu dan tempat.

Perencanaan khilafah ditetapkan oleh akal atau wahyu, atau kolaborasi keduanya. Pertanyaan ini menjadi basis problem teologis muslim yang banyak menyita waktu dan menjadi tema diskusi aktual sehingga memunculkan berbagai pandangan yang sangat beragam. Masalah perumusan metode khilafah ini dikenal dengan nama "al-hussnu wa al-qubhu", apakah baik dan buruk sesuatu ditentukan oleh wahyu atau oleh akal. Masalah ini dibahas dalam berbagai karya ushul al-din dengan judul "alta'dil wa al-tajwir"dan dikenal pula dengan masalah "afalu Allah"atau perbuatan Tuhan

15 Toha Abdurrahman, al-'Amal al-Dini wa al-Tajdid al-Aqli, Beirut: Maarkaz al-Saqofi aal'Arabi, cet.II, 1997, hal. 70

${ }^{16}$ Abdul Halim Mahmud, al-lslam wa alAql, Cet. IV, tt, hal. 330 . 
dari aspek al-wujub dan al-jawaz. Didiskusikan dalam karya Ushul Figh dengan judul "al-Hukm al-Syar 7 ". 17

Sehubungan dengan pembahasan tentang nilai baik dan buruk tentang sesuatu terdapat tiga sub tema penting yaitu: nilai perbuatan manusia (qimatu al-af'al alinsaniyah), apakah perbuatan manusia membawa nilai kebenaran dengan sendirinya ataukah karena faktor dari luar perbuatan manusia; lalu siapakah yang melakukan penilaian terhadap perbuatan manusia itu, apakah akal ataukah wahyu; kemudian apakah suatu perbuatan wajib dikerjakan atau bahkan wajib ditinggalkan.

Aliran Mu'tazilah, Asy'ariyah dan Maturidyah mengemukakan pendapat yang sangat beragam. Namun terlepas dari silang pendapat tersebut, bahwa perbuatan manusia (af'alul insan) mengandung nilainilai inhern (qimaah zatiyah). Nilai-nilai tersebut merupakan bagian dari rencana dan desain Tuhan. Satu-satunya sumber untuk mengungkap nilai adalah wahyu. Sedangkan akal menjadi tempat bergantungnya taklif mampu mengung-kapkan nilai-nilai perbuatan manusia dan mengukurnya dengan cara memahami wahyu. Hanya saja, kemampuan akal dalam melakukan penilaian terhadap perbuatan manusia bersifat relatif dan terbatas sejalan dengan keterbatasan akal manusia itu sendiri. Oleh karena itu jika terdapat wahyu menginformasikan nilai-nilai perbuatan manusia, maka tugas akal adalah memahami informasi tersebut, menjelas-kan pertimbangan-pertimbangan hukum ('ilalul ahkam) dan mencari hikmah di balik penetapan hukumnya oleh Tuhan. Namun jika tidak terdapat wahyu yang menilai perbuatan manusia, maka akal harus menetapkannya dengan cara ijthad dan menggunakan metodologi yang sahih. Perbuatan wajib (al-ijab) bersumber dari Al- lah. Kerja akal untuk mencari wujub itu, bukan menciptakan hukum wujub. Jika tidak terdapat wahyu maka akal tidak memiliki ahliyatul ijabyang berimplikasi pada pahala dan dosa.

Berdasarkan uraian tersebut dengan mempertimbangkan aspek ontologi dan epistemologi ilmu dapat diketahui bahwa manusia mempunyai tugas kekhilafahan (vicegerent) yang "mewakili" Tuhan di muka bumi. Manusia dengan segala dayanya, baik yang inheren maupun daya eksternnya mengemban tugas:

1. Menguasai dan mengontrol bumi ini dengan cara membudidayakannya sebagai sarana beribadah.

2. Menguasai dan menciptakan peradaban dalam rangka beribadah kepada Allah dengan melaksanakan amar ma'ruf nahi munkar. Tugas dan fungsi manusia itu tidak akan terwujud kecualj dengan penguasaan atas ilmu dan teknologi.

Dalam hal membangun fikih lingkungan, maka penalaran harus difokuskan untuk menjawab masalah-masalah dan kasus-kasus hukum yang tidak ada keterangan hukumnya secara tekstual, baik dajam al-Qur'an maupun Sunnah. Dengan meminjam istilah al-Qardhawi ${ }^{18}$ "Fikih Maqosid al-Syari'ah", yang konsentrasinya terletak pada hukum dan tujuan universal. namun maqosid tersebut tetap dalam bingkai maqosid akhlaqiyah (tujuan moral), maqosid insaniyah (tujuan kemanusiaan) dan maqosid mustaqbaliyah (tujuan jangka panjang). Oleh karena itu tahapan-tahapan dalam membangun fikih lingkungan dapat ditempuh dengan mempertimbangkan beberapa pilihan berikut di bawah ini:

17 al-Najjar, Khilafat,h'm.20. 
Pertama, pengkaijian atas Ilmu Ushul Fikih serta kemungkinan mengembangkan metode-metode baru dalam mengembangkan fikih.

Mengkaji dan mengembangkan figh legal maxim dan cara-cara menerapkannya atas kasus-kasus kekinian dan keindonesiaan. tathbi'q al-ahka'm al-mu'ashirah

Kedua, mengembangkan pemikiranpemikiran para filosof Muslim klasik yang sangat diperlukan bagi penguatan pengembangan hukum positif di Indonesia.

Ketiga, membangun proyek islamisasi hukum Islam Indonesia dengan memusatkan perhatian pada penalaran fikih untuk mengembangkan institusi-institusi atau pranata sosial politik.

\section{Metode Istimbath Hukum dalam Pengelolaan Lingkungan}

Masalah lingkungan hidup merupakan kesatuan ruang dengan semua benda, daya, keadaan dan makhluk hidup, termasuk di dalamnya manusia dan perilakunya yang mempengaruhi kelang-sungan kehidupan, kesejahteraan manusia dan makhluk hidup lainnya. ${ }^{19}$ Sekalipun ulama muslim generasi awal sangat intensif mendiskusikan alam dan lingkungan hidup, namun mereka, termasuk Ibn Khaldun, belum sepenuhnya mendiskusikan teknis pengelolaan lingkungan yang dapat dijadikan pedoman secara komprehensif. Atas dasar ini konstruksi metode pengelolaan lingkungan hidup yang imbang harus berorientasi untuk mewujudkan dua tujuan. Pertama, merumuskan kaidah-kaidah umum dan undang-undang universal yang berangkat dari wahyu dan kondisi objektif masyarakat. Kedua, menjamin adanya saling melengkapi antara kaidah-kaidah dan undang-undang yang di-istimbath-kan dari sumber wahyu dan kaidah yang dirumuskan secara induktif dari fakta sosial yang ada.

Ayat-ayat al-Qur'an tidak mendiskusikan satu pokok permasalahan secara tuntas dalam rangkaian ayat yang berurutan, bahkan satu persoalan dibahas di dalam berbagai ayat daiam surat yang berbeda-beda. Oleh karena itu, kemam-puan seseorang dalam memahami satu persoalan erat hubungannya dengan kemampuan yang dimiliki dalam menghubungkan satu ayat dengan ayat yang lain. Maka, dengan mencermati satu ayat untuk menghukumi suatu perbuatan manusia akan berdampak pada kesalahpahaman dalam memahami tujuan wahyu. Dari sini tampak bahwa istimbath hukum untuk suatu permasalahan membutuhkan pencermatan ayat-ayat alQur'an secara tematis dan terorganisir melalui empat proses. 1). Tahap identifikasi ayat tentang masalah-masalah sejenis, 2). Tahap memahami ayat sesuai dengan kaidah yang berlaku, 3). Memahami illat atau tujuan hukum yang dikandung dalam nashnash tersebut, 4). Merakit dan mengikat hukum-hukum yang dipahami dari nashnash tersebut. Produk hukum dari hasil kolaborasi atau pemahaman dari sejumlah nash ini merupakan hukum yang niscaya dan pasti. Karena hukum dari produk nash yang tunggal tidak mungkin-seperti ditegaskan Syatibi-sampai pada tingkatan yang pasti (baca qath'). ${ }^{20}$

Untuk merumuskan hukum hasil kolaborasi sejumlah nash sekaligus mencari tujuan Tuhan maka beberapa asas harus diperhatikan. Pertama, asas bahasa Arab (al-asas al-lughawi). Karena wahyu

is Yusuf al-Qordhawi, al-Sunnah Masdaran li al-Ma'rifah wa al-Hadharah, Kairo: Dar aal-Syuruq, Cet. IIl, 22002 M/11423 H, hal. 231

19 Ali Yafie, Menggagas Figh Sosial, Bandung: Mizan, Cet. l, 1994, hal, 140. 
menggunakan bahasa Arab maka berlaku pula aturan dan kaidah bahasa Arab. Kedua, asas tujuan syari'ah (al-asas al-magosidi). ${ }^{21}$ Wahyu mengandung tujuan-tujuan Tuhan. Tujuan-tujuan tersebut secara umum adalah kemaslahatan manusia dan menjamin kebahagiaan mereka di dunia dan di akhirat. Menurut Imam Syatibi kemaslahatan manusia meliputi lima hal yaitu agama, jiwa, harta, keturunan dan akal.

Ketiga, asas situasi dan kondisi sosial masyarakaat (al-asas al-zorfi). Asas inibisa dipahami dengan cara mengetahui sebabsebab turunnya ayat atau kondisi sosial masyarakat pada saat itu. Namun bisa juga dengan memperhatikan situasi dan kondisi sosial masyarakat sekarang. Asas ini dapat disebut asas kearifan lokal. Sehubungan dengan ini maka kaidah ushuliyah yang mengatakan al-hukmu yaduru ma'a 'illatihi wujudan wa 'adaman membutuhkan revisi secara redaksional yaitu al-hukmu yaduru ma'a hikamihi wa al-biah wujudan wa 'adaman (keberadaan hukum sangat tergantung pada hikmah dan situasi-kondisi masyarakat).

Keempat, asas saling melengkapi (alasas al-takamuli). Al-Qur'an maupun hadis merupakan satu kesatuan yang saling melengkapi. Dengan kata lain, al-Qur'an adalah sumber hukum yang dilengkapi oleh hadis yang juga sebagai wahyu. Hadis sesungguhnya merupakan praktik faktual Nabi sehingga dapat dikatakan sebagai cermin dari kearifan lokal masyarakat pada saat diturunkan wahyu. Tentu saja praktik faktual yang terjadi di tengah masyarakat saat itu dapat dilegalkan manakala tidak bertentangan dengan prinsip-prinsip umum syari'ah. Contoh konkret dalam masalah ini, adalah transaksi dengan skim mudarabah. Sebetulnya al-Qur'an tidak pernah berbicara mudarabah secara langsung. Melegalkan praktik mudarabah dengan ayat faiza darabtumcenderung memaksakan wajhualdalalah atau indikasi dalil yang tidak relevan dengan ayat. Terlepas dari itu konsep mudarabahadalah praktik ekonomi jahiliyah yang dilegalkan oleh Islam melalui hadis. Praktik mudarabah dianggap adil dan menghindari sikap eksploitasi. Kearifan lokal juga dapat dijadikan alat bantu dalam memahami dan menjelaskan ayat-ayat yang mujmal. Hal ini dapat dilakukan manakala kearifan lokai dikategorikan sebagai "ijma"' masyarakat muslim.

Kelima, asas rasional (al-asas al-agli). Asas ini tidak bermaksud untuk membuka pintu rasionalisme tanpa batas, melainkan lebih pada ilmu-ilmu pendukung bagi proses penetapan hukum. Karena ijtihad sudah seharusnya menjadi sebuah formulasi metodologi, dibentuk dari hasil kajian kritis terhadap fenomena perubahan yang dipadukan dengan tuntutan zaman. la memerlukan argumentasi deduktif sebagai wujud sumber asal dan dalam waktu yang sama juga memerlukan argumentasi induktif atau empirik sebagai ciri akademik dan realitas. Sehingga hukum Islam yang dihasilkan dari ijtihad ini benar-benar dapat membangun masyarakat yang modem, kaya (prosperous), adil, makmur, aman dalam kehidupan yang plural di tengah-tengah era globalisasi.

ljtihad dalam menghadapi lingkungan mungkin dapat dilakukan secara tematik kasus perkasus dan juga untuk semua aspek kehidupan umat. jjtihad akademik menggunakan prosedur keilmuan seperti

${ }^{20}$ Syatibi, al-Muwafaaqat fi Ushul alSyari'ah, Beirut: Dar al-Ma'rifah, tt, hal. I/39.

21 Ahmad al-Raisuni dan Muhammad Jamal Barut, al-ljtihad, al-Nas, al-Waqi' alMaslahah, Damaskus: Dar al-Fikr al-Mu'asir, Cet. I, 2000. 
lazimnya yang terjadi dalam dunia akademik dan ditandai oleh metode induktif dan empirik. Sehingga perlu ada argumentasi dan perbandingan sebagai prosedur yang dibenarkan oleh ushul fikih dan logika. Di samping itu ijtihad akademik, harus mencakup pengertian menggunakan produk sains dan teknologi dalam proses dan prosedur berijtihad atau penentuan hukum Islam. Sehingga muncul pula hukum yang mampu menjadi ruh dan landasan untuk pengembangan sains dan teknologi dalam rangka mewujudkan kemaslahatan umat masa kini dan masa yang akan datang. Tentunya sejalan dengan semboyan hukum Islam dan menjadi tantangan masyarakat muslim yaitu "litahqiq al-masolih al-anam" dan rahmatan li al-'alamin. Sehingga ijtihad dalam bidang lingkungan hidup diarahkan untuk memperoleh landasan, pedoman, petunjuk dan sekaligus arah ke depan beserta legitimasi dalam pengelolaan lingkungan yang dinamis, humanis, terarah dan ramah.

Semua asas yang menjadi patokan berijtihad tersebut seyogiyanya diorientasikan untuk mewujudkan tiga dimensi almasalih yaitu al-masalih al-maddiyah (kemaslahatan material), al-masalih alruhiyah (kemaslahatan spiritual) dan almasalih al-aqliyah (kemaslahatan intelektuai). ${ }^{22}$ Untuk mewujudkan ketiga dimensi al-masalih tersebut, maka pendekatan ijtihad yang dinamis dan kreatif harus difokuskan pada nalar ta'lil al-go'i atau kausasi tujuan syariah.

\section{Penutup}

Persoalan lingkungan, sesungguhnya menjadi persoalan serius bagi kehidupan manusia. Apabila dilihat dari status kekhalifahan manusia, mereka memiliki hak dan wewenang untuk menetapkan berbagai aturan yang bertujuan untuk menata dan melindungi lingkungan. Hukum-hukum tersebut harus mempertimbangkan asas bahasa, asas tujuan hukum, asas situasi dan kondisi masyarakat, asas rasional serta asas saling melengkapi.

Kelima asas di atas untuk mendukung upaya mewujudkan tiga dimensi al-masalih yang dibutuhkan manusia yaitu kemaslahatan material, kemaslahatan spiritual dan kemaslahatan intelektual. Secara fungsionil ketiga dimensi kemaslahatan tersebut dapat direalisasikan melalui nalar ta'lil al-go'iatau kausasi tujuan syariah, sehingga hukum yang dihasilkan lebih akomodatif, ramah dan humanis.

\section{Daftar Pustaka}

Abd Rahman, Toha, 1994, Tajdid al-Minhaj fi Taqwim al-Turas, Beirut: al-Markaz al-Saqofi al-'Arabi, Cet. I,.

Abdul Halim Mahmud, al-Islam wa al-Aql, Cet. IV, tt.

Abdul Halim Mahmud, Falsafah a/Tashawwuf, al-Risalat al-Qusyairiyah, Kairo (n.d).

Abdurrahman, Toha, al-'Amalal-Dini wa alTajdid al-Aqli, Beirut: Markaz alSaqofi al-'Arabi, cet.II

Fuad Sizkin, Tarikh al-Hadlarat wa al-'Ulum al-Islamiyah (Sejarah Peradaban dan Ilmu-llmu Islam), Riyadh, Universitas King Abdul Aziz; Abu Ya'la, “al'Uddah fi Syarh al-'Umdah", dan syarahnya al-Kawkab al-Munir;

22 Toha Abd Rahman, Tajdid al-Minhaj fi Taqwim al-Turas, Beirut: al-Markaz al-Saqofi al'Arabi, Cet. I, 1994, hlm. 80. 
Ibn Taymiyah, Al-Radd 'ala al-Manthiqiyin (Sanggahan terhadap Ahli-ahli Logika), Mesir, (n.d); Ibn Sina, alHidayah, Kairo, (n.d).

'Imaarah, Muhammad, Ma'alim al-Minhaj atIslami,Herndon, Virginia: al-Ma'had al'Alami li al-Fikr al-Islami, Cet. II, 1411 H/1991.

Juhaya, Paradigma Pengembangan Universitas Islam Negen: Harapan dan Masa depan UIN Malang, dalam Horizon Baru Pengembangan Pendidikan Islam, 2004, M. Zainuddin dan In'am Esha (editor), Malang: UIN Press,.

Khalaf, 'Abdul Wahab, 1978, 'Ilmu Ushul AlFiqh, Cairo:Dar Al-Qalam.

Khin, al Musthafa Said, 2000, al-Kafial-Wafi fi Ushul al-Figh al-Islamy, Beirut : Muassasah Risalah.

Malkawy dan Muhammad Abdu al-Karim Abu Sal, $1995 \mathrm{M} / 14116 \mathrm{H}$, Buhus Mu'tamar 'Ulum al-Syari'ah fi alJami'at, Amman Yordania: al-Ma'had al-'Alami li al-Fikr al-Islami, Cet. I.

Muhammad, Muhammad al-Madani, 1422 H/2001 M, Khasais al-Qur'an alKarim, Cet. I, tp.

Muhsin, Abdul Hamid, $1416 \mathrm{H} / 1996$ M, Tajdid al-Fikr al-Islami, Herndon, Vir- ginia: al-Ma'had al-'Alami li al-Fikr alIslami, Cet. I.

Najjar, Abdul Majid, 1993 M, Khilafat ai-Insan bain al-Wahyu wa al-Agl, Herndon, Virginia: al-Ma'had al-'Alami li al-Fikr a!-Islami, Cet. II.

Praja, Juhaya, Paradigma \& Penalaran Fiqh dalam Konteks Kekinian dan Keindonesiaan, makalah disampaikan dalam conference PPS IAIN/UIN se-Indonesia IAIN Ar-Paniry Darussalam Banda Aceh 1-5 Desember 2004.

Raisuni, Ahmad dan Barut, Muhammad Jamal,2000, al-litihad , al-Nas, alWagi' al-Maslahah, Cet. I.Damaskus: Dar al-Fikr al-Mu'asir.

Sofi, Luway, Nahwa Minhajiyah Ushuliyah if al-Dirasat al-Islamiyah dalam Fathi Hasan

Syatibi, Abu Ishaak, al-Muwafaqat fi Ushul al-Syari'ah, Beirut: Dar al-Ma'rifah, tt, hal. $1 / 39$.

Yafie, Ali,1994, Menggagas Figh Sosial,cet. I, Bandung: Mizan.

Yusuf al-Qordhawi,2002 M/1423 $\mathrm{H}$ alSunnah Masdaran li al-Ma'ifah wa alHadharah, Kairo: Dar aal-Syuruq, Cet. III. 